\title{
Laparoscopic management of persistent gastrocutaneous fistula after feeding gastrostomy appliance removal in children
}

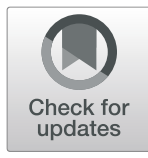

Mohammad Gharieb Khirallah ${ }^{1 *}$ and Nasir Bustangi ${ }^{2}$

\begin{abstract}
Background: Feeding gastrostomy is widely used in children that have troubles of swallowing and need to stablish enteral feeding. There are several methods for creation of that stoma. After the children gain their normal ability of swallowing, this tube or appliance is removed. Failure of spontaneous closure of gastrostomy opening after removal of the tube was reported with an incidence of 0.5 to $3.9 \%$. The purpose of authors was to study laparoscopic management of persistent gastrocutaneous fistula after failure of conservative measures.

Results: There were 19 patients, 12 males. Main cause for feeding gastrostomy was neurological. Most feeding gastrostomy tubes were inserted endoscopically. The mean operative time was $57 \pm 10.2 \mathrm{~min}$. The mean time of full oral intake was $24 \pm 3.5 \mathrm{~h}$. No wound infection had developed. There was no recurrence of fistula after management.
\end{abstract}

Conclusion: Laparoscopic management of persistent gastrocutaneous fistula is safe, feasible, and associated with no recurrence of fistula.

Keywords: Laparoscopic, Gastric fistula, Children

\section{Background}

There is a wide range of indications for feeding gastrostomy in children. Several techniques are used to insert feeding gastrostomy tubes either surgical or endoscopic [1].

Creation of a stoma for enteral feeding is not free of complications. The incidence of these complications ranges from 2 to $60 \%$. One of these complications is failure of spontaneous closure of gastrostomy opening after removal of tube with an incidence of 0.5 to $3.9 \%[2,3]$.

It is expected that spontaneous closure of gastrocutaneous fistula opening takes place within 1 to 3 months after removal of tube or gastric button [4].

\footnotetext{
* Correspondence: Mohamed.khirallah@med.tanta.edu.eg

'Department of Pediatric Surgery, Tanta University, El-geish street, Tanta, Egypt

Full list of author information is available at the end of the article
}

Authors evaluated laparoscopic management of persistent gastrocutaneous fistula after failure of conservative measures.

\section{Methods}

The study was carried out on infants and children that suffered from persistent gastrocutaneous fistula after feeding gastrostomy tube removal. It included 19 children. All of them failed to have spontaneous closure or failed nonsurgical management (Fig. 1).

Laparoscopic intervention was planned. Three ports were used: a telescope, $\left(30^{\circ}\right) 5 \mathrm{~mm}$, was passed through the umbilical port, and two ports were inserted at both midclavicular lines above level of umbilicus. Exploration of peritoneal cavity was the first step (Fig. 2).

Any collection related to the fistula was cleared out. Separation of the stomach from the anterior abdominal wall was the second step (Fig. 3).
Springer Open (c) The Author(s). 2020 Open Access This article is licensed under a Creative Commons Attribution 4.0 International License, which permits use, sharing, adaptation, distribution and reproduction in any medium or format, as long as you give appropriate credit to the original author(s) and the source, provide a link to the Creative Commons licence, and indicate if changes were made. The images or other third party material in this article are included in the article's Creative Commons licence, unless indicated otherwise in a credit line to the material. If material is not included in the article's Creative Commons licence and your intended use is not permitted by statutory regulation or exceeds the permitted use, you will need to obtain permission directly from the copyright holder. To view a copy of this licence, visit http://creativecommons.org/licenses/by/4.0/. 


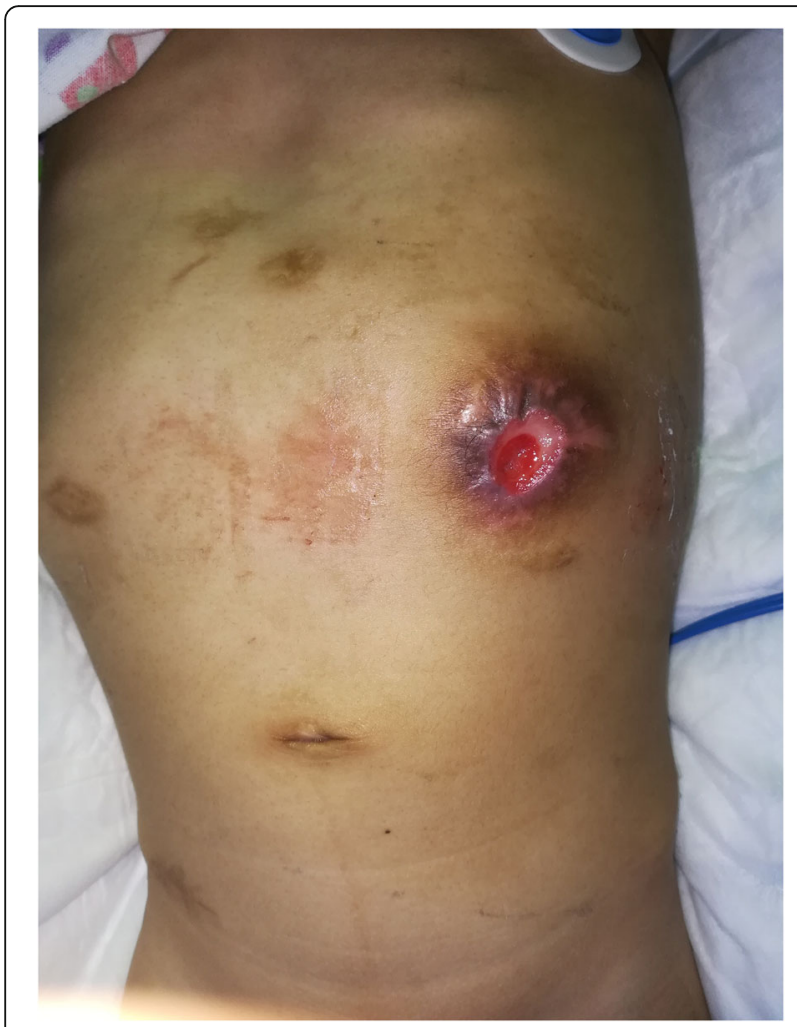

Fig. 1 Persistent gastrocutaneous fistula

Trimming of the edges of the stoma on the anterior wall of the stomach was done. If the resultant defect was small, it was hand sewn (Fig. 4).

A linear endoscopic stapler was used to close the gastric defect in some cases (Fig. 5).

Peritoneal irrigation was performed. Cauterization of interior part of the anterior abdominal wall at the site of fistula was done. External curettage of the fistula site on the anterior abdominal wall was performed. Wounds

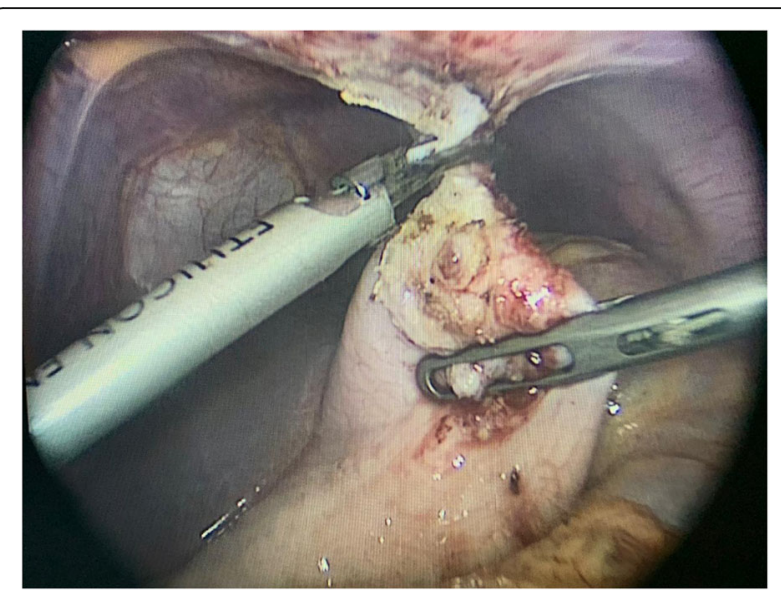

Fig. 3 Separation of the stomach from the anterior abdominal wall

were closed. According to our protocol of initialization of oral intake following laparoscopic interventions, patients started oral intake $4 \mathrm{~h}$ postoperatively. They continued oral intake as they tolerated till they reached full oral intake.

\section{Results}

\section{Preoperative and demographic data}

The study included 19 children with persistent gastrocutaneous fistula that failed to close either spontaneously or with other conservative measures. The fistula was considered persistent if it did not close after 3 months of removal of the tube.

Indications for feeding gastrostomy insertion in these children are summarized in Table 1 . There were 12 males and 7 females. Thirteen children had percutaneous endoscopic gastrostomy tube, four children had conventional surgical insertion, and two cases had laparoscopic insertion of gastrostomy tube. The mean duration of gastrostomy tubes from insertion to closure

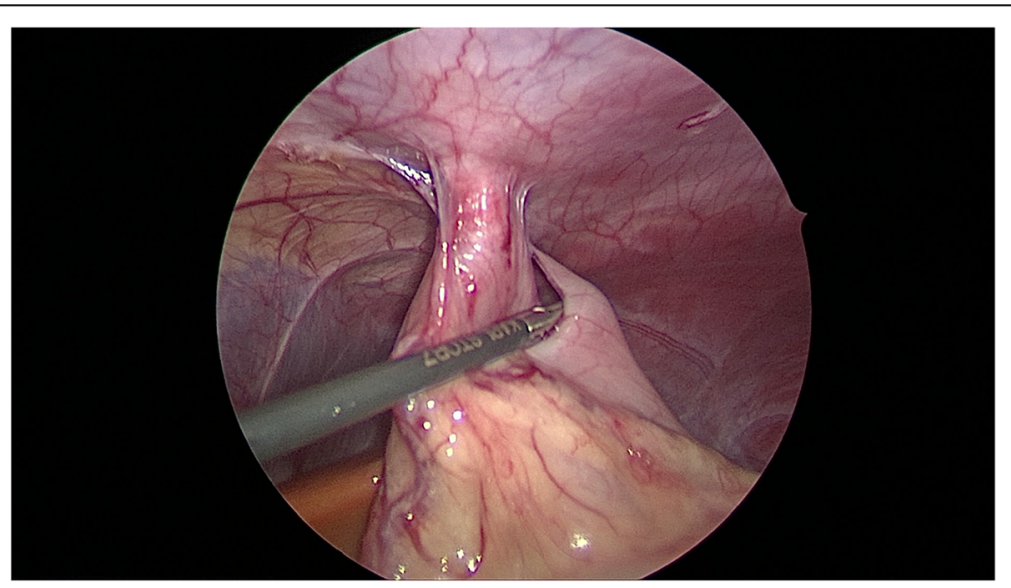

Fig. 2 Exploration and examination of fistula track 


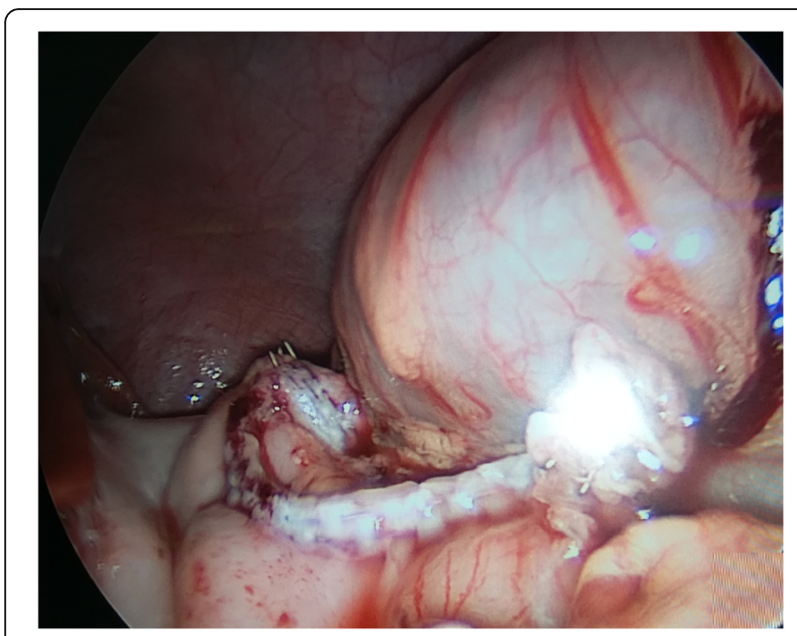

Fig. 5 Large defect managed using a straight endoscopic stapler

was 1.7 years \pm 0.5 years. The mean duration of nonoperative management was $3.5 \pm 1.2$ months. The mean age at operation was 5.4 years \pm 4.2 years (Table 1 ).

\section{Operative data}

Collection related to fistula tract was found in 7 cases. In three cases, there was malpositioned one or more of fixing hocks of percutaneous endoscopic gastrostomy tube. These hocks passed through stoma to fistula tract and acted as foreign body. Other cases showed no detected abnormality.

The mean operative time was $57 \mathrm{~min} \pm 10.2$. No accidental hemorrhage or visceral injury was encountered. Endoscopic linear stapler was used in 3 cases. In the

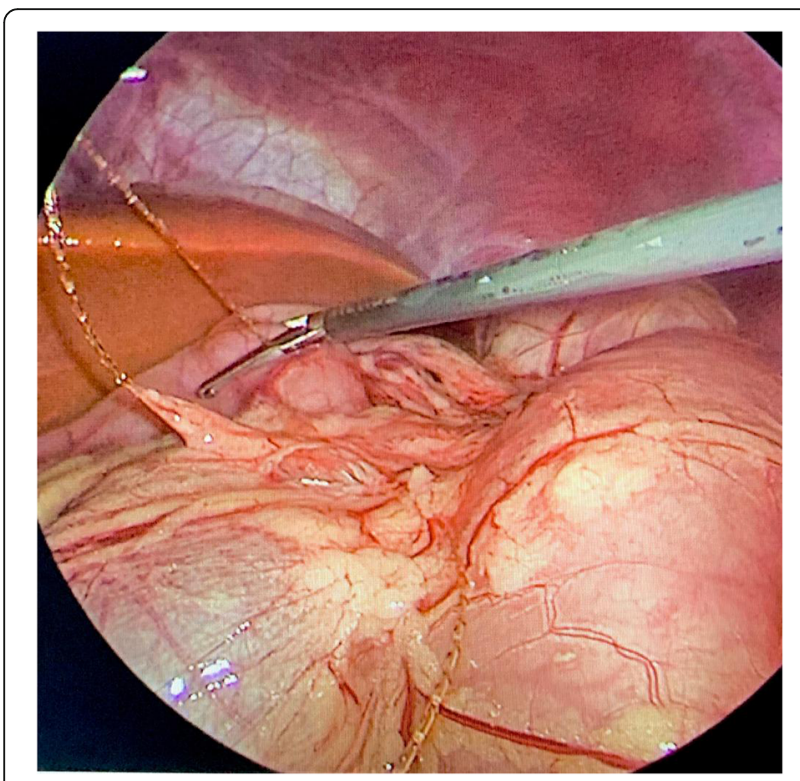

Fig. 4 Hand-sewn defect after trimming
Table 1 Demographic and preoperative data

\begin{tabular}{|c|c|c|}
\hline & $\begin{array}{l}\text { No. of cases } \\
\text { (19) }\end{array}$ & $\%$ \\
\hline \multicolumn{3}{|l|}{ Indications for gastrostomy tube: } \\
\hline Neurological diseases & 7 & 36.8 \\
\hline Long gap esophageal atresia & 4 & 21 \\
\hline Esophageal corrosive & 3 & 15.7 \\
\hline $\begin{array}{l}\text { Failure to thrive due to upper airway } \\
\text { problems }\end{array}$ & 5 & 26.3 \\
\hline \multicolumn{3}{|l|}{ Sex } \\
\hline Male & 12 & 63.15 \\
\hline Female & 7 & 36.84 \\
\hline \multicolumn{3}{|l|}{ Insertion of gastrostomy } \\
\hline PEG & 13 & 68.42 \\
\hline Laparoscopic & 2 & 10.52 \\
\hline Open surgery & 4 & 21.05 \\
\hline \multicolumn{3}{|c|}{ Duration of feeding gastrostomy tube (mean in years) } \\
\hline$<6$ months & 6 & 31.57 \\
\hline $6-12$ months & 10 & 52.6 \\
\hline$>12$ months & 3 & 15.78 \\
\hline \multicolumn{3}{|c|}{ Mean duration of conservative measures (mean in days) } \\
\hline$<30$ days & 7 & 36.84 \\
\hline $30-50$ days & 10 & 52.6 \\
\hline$>50$ days & 2 & 10.52 \\
\hline \multicolumn{3}{|l|}{ Age at operation (mean in years) } \\
\hline $1-1.5$ years & 4 & 21.05 \\
\hline $1.5-5$ years & 12 & 52.6 \\
\hline $5-7.5$ years & 3 & 15.78 \\
\hline
\end{tabular}

other 16 cases, stoma was closed with PDS or Vicryl size $3 / 0$ sutures in continuous manner. No drain was used in all patients. The mean duration to full enteral feeding was $24 \mathrm{~h} \pm 3.5 \mathrm{~h}$. The mean hospital stay was $48 \mathrm{~h} \pm 6.3$ $h$. No recurrence or failure of management was recorded (Table 2).

\section{Discussion}

There are different factors that contribute to persistent gastrocutaneous fistula in children after its removal. Age of patient at time of insertion, method of insertion, and duration of gastrostomy tube are most common factors related to failure of spontaneous closure [5].

There are several conservative measures that helped and promoted spontaneous closure. They included curettage of external opening of fistula track and then curettage by silver nitrate, improving gastric emptying, decreasing intragastric pressure, and reducing gastric acidity [6]. 
Table 2 Operative and postoperative data

\begin{tabular}{|c|c|c|}
\hline & No of cases $(N=19)$ & $\%$ \\
\hline \multicolumn{3}{|l|}{ Collection } \\
\hline Present & 7 & 36.84 \\
\hline Absent & 12 & 63.15 \\
\hline \multicolumn{3}{|l|}{ Foreign bodies } \\
\hline Present & 3 & 15.78 \\
\hline Absent & 16 & 84.21 \\
\hline \multicolumn{3}{|c|}{ Mean operative time in $\min (57 \pm 10.2)$} \\
\hline$<50 \min$ & 10 & 52.63 \\
\hline$>50 \min$ & 9 & 47.36 \\
\hline \multicolumn{3}{|l|}{ Closure of gastric defect } \\
\hline Hand sewn & 16 & 84.21 \\
\hline Endoscopic stapler & 3 & 15.78 \\
\hline \multicolumn{3}{|c|}{ Mean time for full oral intake in hours $(24 \pm 3.5)$} \\
\hline$<12 \mathrm{~h}$ & 5 & 26.31 \\
\hline$>12 \mathrm{~h}$ & 14 & 73.68 \\
\hline \multicolumn{3}{|c|}{ Mean hospital stay in h $(48 \pm 6.3)$} \\
\hline$<24 h$ & 11 & 57.89 \\
\hline$>24 h$ & 8 & 42.1 \\
\hline Recurrence & No cases & \\
\hline Wound infection & No cases & \\
\hline
\end{tabular}

Some studies reported the use of tissue-sealing substances as collagen or cyanoacrylate with nonocclusive results. These approaches had the advantages that they did not require general anesthesia and can be performed as outpatient procedure [7].

Other studies demonstrated the use of endoscopic approach to close gastrocutaneous fistula. Several techniques were used with high success rate in some of them and some recurrences in others. These endoscopic techniques included cauterization, clipping, suturing, banding, and use of mesh and tissue glue. One of the advantages of endoscopic closure approach was that healing immediately occurred. The incidence of recurrence ranged from 0 to $35 \%$. Disadvantage of these techniques included the high costs of used instruments [8-10].

Conventional surgical management of failed spontaneous closure of gastrocutaneous fistula remained the main line of treatment. The traditional approach depended on mini laparotomy, fistula track excision, and repair of the stomach in two layers [11].

Singhal and his colleagues described extraperitoneal excision of fistula track and closure of stoma as a procedure with minimal invasiveness. Their children stayed at a hospital for about 3 days. Oral intake was tolerated within 2 days postoperatively. The overall recurrence rate was $4.1 \%$ [10].
During current study, authors used laparoscopic technique to disconnect the stomach from the anterior abdominal wall and close stoma either by linear stapler or traditional sutures.

The main advantages of laparoscopic approach were detecting and dealing with any cause that might have led to failure of spontaneous closure and separation of gastric wall from the abdominal wall.

The mean hospital stay duration was 2 days, and infants and children started oral intake once tolerated with a mean duration of $24 \mathrm{~h}$.

No recurrence occurred in the current study. Although endoscopic technique has its many advantages, its approach does not include separation of stomach from the abdominal wall. This may make circumstances suitable for recurrence after management. Also, another cause for recurrence after endoscopic intervention was the inability of clips used by some authors to completely enclose the stoma. These patients were treated by conventional surgical approach [12].

\section{Conclusion}

Laparoscopic closure of persistent gastrocutaneous fistula after removal of feeding gastrostomy tube is safe, effective, and more exploratory with no recurrence after management, and has a short hospital stay.

\section{Acknowledgements}

None

\section{Authors' contributions}

All authors contributed equally in the writing of this manuscript. M G Kh: contributed specifically in patient selection, partitioning, and operative technique. N B: participated mainly in the study designing and the operative technique. All authors have read and approved the manuscript and ensure that this is the case.

\section{Funding}

None

Availability of data and materials

The datasets used and/or analyzed during the current study are available from the corresponding author on reasonable request.

Ethics approval and consent to participate

Approval was obtained from the Research Ethics committee at our faculty of medicine with approval code 33873/6/20. Parents of each patient were informed about all the steps in the procedure.

A written consent was obtained from study participants.

Consent for publication

Agree to consent for publication

\section{Competing interests}

None

\section{Author details}

${ }^{1}$ Department of Pediatric Surgery, Tanta University, El-geish street, Tanta, Egypt. ${ }^{2}$ Division of Pediatric Surgery, King Abdul-Aziz University Hospital, Jeddah, Saudi Arabia. 
Received: 17 July 2020 Accepted: 20 October 2020

Published online: 16 December 2020

\section{References}

1. Baker $L$, Beres Al, Baird R. A systemic review and meta-analysis of gastrostomy techniques in children. J Pediatr Surg. 2015;50:718-25.

2. Miyata S, Dong F, Lebedevsky $\mathrm{O}$, et al. Comparison of operative outcomes between surgical gastrostomy and percutaneous endoscopic gastrostomy in infants. J Pediatr Surg. 2017:52:1416-20.

3. Khan FA, Fisher JG, Sparks EA, et al. Factors affecting spontaneous closure of gastrocutaneous fistulae after removal of gastrostomy tubes in children with intestinal failure. J Parenteral Enteral Nutr. 2015;39(7):860-3.

4. Arnbjornsson F, Backman T, Berglund Y, et al. Closure after gastrostomy button. Pediatr Surg Int. 2005;21:797-9.

5. Thomas PG, Sharp NE, Schnell K, et al. The role of medication in spontaneous gastrocutaneous fistula closure. Eur J Pediatr Surg. 2015;25: 405 e408.

6. Vasant DH, Lal S, Blackett BD, et al. Closure of a large high-output gastrocutaneous fistula with combined postpyloric feeding and aggressive medical therapy. BMJ Case Rep. 2012;2012.

7. Gonzalez-Ojeda A, Avalos-Gonzalez J, Mucino-Hernandez Ml, et al. Fibrin glue as adjuvant treatment for gastrocutaneous fistula after gastrostomy tube removal. Endoscopy. 2004;36:337-41.

8. Teitlebaum JE, Gorcey SA, Fox VL. Combined endoscopic cautery and clip closure of chronic gastrocutaneous fistulas. Gastrointest Endosc. 2005;62(3): 432-5.

9. Lukish J, Marmon L, Burns C. Nonoperative closure of persistent gastrocutaneous fistulas in children with 2-octylcyanoacrylate. J Laparoendosc Adv Surg Tech. 2010;20(6):565-7.

10. Singhal S, Malieckal A, Changela K, et al. Endoscopic closure of gastrocutaneous fistulas using over-the-scope clip (OTSC): a case series. Am J Gastroenterol. 2013;108:S618-9.

11. Farach SM, Danielson PD, McClenathan DT, et al. Endoscopic closure of persistent gastrocutaneous fistula in children. Pediatr Surg Int. 2015;31: $277 e 281$.

12. Pierog A, Mercedes M, Ali M. Outpatient endoscopic closure of persistent gastrocutaneous fistula with hemoclips in pediatric patients. Gastrointestinal endoscopy. 2014:1190-3.

\section{Publisher's Note}

Springer Nature remains neutral with regard to jurisdictional claims in published maps and institutional affiliations.

\section{Submit your manuscript to a SpringerOpen ${ }^{\odot}$ journal and benefit from:}

- Convenient online submission

- Rigorous peer review

- Open access: articles freely available online

- High visibility within the field

- Retaining the copyright to your article

Submit your next manuscript at $\boldsymbol{\nabla}$ springeropen.com 